medRxiv preprint doi: https://doi.org/10.1101/2021.07.14.21260238; this version posted July 18, 2021. The copyright holder for this preprint (which was not certified by peer review) is the author/funder, who has granted medRxiv a license to display the preprint in perpetuity.

It is made available under a CC-BY 4.0 International license .

\title{
Gender Based Differences in Risks and Comorbidities in Patients Hospitalized with Acute Exacerbation of COPD: A Retrospective Observational study in Eastern-Nepal
}

Nischit Baral ${ }^{\mathrm{a}}$, MBBS, Nabin R. Karki ${ }^{\mathrm{c}}$, MD, Prem Raj Parajuli ${ }^{\mathrm{d}}$, MD, Laura Bell ${ }^{\mathrm{b}}$, MD, Bidhan Raj Paudel ${ }^{\mathrm{e}}$, MBBS, Anish C. Paudel ${ }^{\mathrm{d}}$, MD, MD, Nirajan Adhikari ${ }^{\mathrm{f}}$, MD, Pankaj Luitel ${ }^{\mathrm{g}}$, MD, Narendra Bhatta ${ }^{\mathrm{b}}$, MD, MSc

a: B.P. Koirala Institute of Health Science, Nepal b: Michigan State University c: Augusta University, USA d: Tower Health/Reading Hospital, USA e: Kathmandu University f: Guthrie Robert Packer Hospital g: AMITA Health/Saint Francis Hospital

1. Nischit Baral, MBBS, Intern, B. P. Koirala Institute of Health Science, Nepal, nischitbaral@gmail.com

2. Nabin Raj Karki, MD, B. P. Koirala Institute of Health Science, Nepal/ Augusta University, GA nbnraj@hotmail.com

3. Prem Raj Parajuli, MD, Internal Medicine, Tower health/Reading Hospital Premrajparajuli@gmail.com

4. Laura Bell, MD, MS4, Michigan State University College of Human Medicine

bellla11@msu.edu

5.Bidhan Raj Poudel, MBBS, Intern, Kathmandu University, bidhanraj.paudel@gmail.com

6. Anish C. Paudel, MD, Internal Medicine, Tower Health/Reading Hospital anish_paudel@outlook.com

7. Nirajan Adhikari, MD, Internal Medicine, Guthrie Robert Packer Hospital, USA neerjan.adh@gmail.com

8. Pankaj Luitel, MD, Internal Medicine, AMITA Health/Saint Francis Hospital, USA mepunkazz@gmail.com

9. Narendra Bhatta, MD, Division of Pulmonary, Critical Care, and Sleep medicine, Internal Medicine, B. P. Koirala Institute of Health Sciences, Nepal bhattanarendra@ hotmail.com

Address for correspondence: Nischit Baral, MBBS, Department of Internal Medicine, B.P. Koirala Institute of Health Sciences, Dharan, Nepal. Email: nischitbaral@gmail.com Lekhnath Municipality, Talchowk, Pokhara, Nepal, +9779846038078

FUNDING: NONE

DISCLOSURE: All the authors have no relationships relevant to the contents of this paper to disclose

ACKNOWLEDMENTS: None

NOTE: This preprint reports new research that has not been certified by peer review and should not be used to guide clinical practice. 1 


\section{Abstract}

Background: Acute Exacerbation of Chronic Obstructive Pulmonary Disease (AECOPD) share a complex relationship with gender, risk, and co-morbidities. There is paucity of data on the gender-based differences in the prevalence of risks and co-morbidities in AECOPD in Nepal.

Methods: We performed a retrospective cross-sectional study where data were collected from medical records of adult patients (age $>40$ years), hospitalized with clinical diagnosis of AECOPD in a tertiary level University hospital in eastern Nepal from April 15, 2014 to October 15, 2014 were included. Data analysis was performed by using SPSS software (Version 26.0, 2020; SPSS Inc., Chicago, IL).

Results: Of the 256 patients with the primary diagnosis of AECOPD, mean age was 69 years and $65.63 \%$ ( $n=168$ ) of hospitalizations were female population. Compared to males, $64.32 \%$ $(\mathrm{n}=137)$ of active smokers were females $\mathrm{p}=0.299,76.19 \%(\mathrm{n}=32)$ of diabetics were females $\mathrm{p}=$ $0.155,72.86 \%(n=51)$ of hypertensive were females, $p=0.143,50 \%(n=6)$ of underlying Atrial fibrillation were in females $\mathrm{p}=0.350,57.50 \%(\mathrm{n}=23)$ of anemics were females $\mathrm{p}=0.278,100 \%$ $(\mathrm{n}=3)$ of asthmatics were females $\mathrm{p}=0.553,44.44 \%(\mathrm{n}=8)$ of Pulmonary tuberculosis were in females $\mathrm{p}=0.070$, and $78.76 \%(\mathrm{n}=89)$ of indoor air pollution exposure was in females $\mathrm{p}<0.001$.

Conclusion: Females have higher association to indoor air pollution exposure compared to male and this association was found to be statistically significant. The higher incidence of AECOPD hospitalization in females can be explained by these findings. We need larger studies to validate these findings.

Keywords: Acute Exacerbation of Chronic Obstructive Pulmonary Disease, Retrospective observational study, Female Gender, Indoor Air Pollution

Introduction: 
medRxiv preprint doi: https://doi.org/10.1101/2021.07.14.21260238; this version posted July 18, 2021. The copyright holder for this preprint (which was not certified by peer review) is the author/funder, who has granted medRxiv a license to display the preprint in perpetuity.

It is made available under a CC-BY 4.0 International license.

Chronic Obstructive Pulmonary Disease (COPD) is defined as a progressive and incompletely reversible obstructive lung disease that is characterized by persistent respiratory symptoms and airflow limitations. AECOPD is the acute exacerbation of COPD with clinical symptoms of increased Shortness of breath or cough with or without sputum production in patients with COPD. COPD is pathologically characterized by airway and/or alveolar abnormalities usually caused by significant exposure to noxious particles or gases(1). COPD is the most common chronic respiratory condition in Nepal(2). COPD can lead to pulmonary artery hypertension resulting from the damage of structure and function of the lung. This results in right ventricular enlargement and with time may lead to right heart failure(3). Nepal is an agricultural country where females work mostly indoor cooking food with biomass fuel like firewood and cow-dung. Many of these females also smoke tobacco. According to the Nepal Demographic and Health Survey $2016,27 \%$ of the Nepalese males and $6 \%$ of females smoked tobacco, $66 \%$ of households used solid fuel for cooking, and $31 \%$ of households were exposed to second-hand smoke or indoor air pollution (IAP) so our study also highlights the gender wise difference in prevalence of AECOPD (4).We reported the differences of comorbidities and risks between male and female gender in patients hospitalized with AECOPD in the Eastern part of Nepal.

Pathogenesis:

The pathogenesis of AECOPD involves long standing alveolar hypoxia and endothelial dysfunction by noxious particles or gases. This induces pulmonary vascular remodeling. With increasing pulmonary vascular remodeling, there is increased pulmonary vascular resistance causing Pulmonary Artery Hypertension (PAH) (5) (6). Some studies reported that the reduced lung function which is a characteristic of COPD can be a risk factor for development of DM and 
other co-morbidities $(7,8)$. Moreover, the inflammatory markers like TNF- $\alpha$, IL-6, and CRP, are elevated in AECOPD $(9,10)$. However, the role of female gender in the development of AECOPD is not well understood.

Objective: To explore the gender-based difference in risks and comorbidities of hospitalizations with AECOPD in Eastern-Nepal.

Materials and Methods:

This is a retrospective observational cross-sectional study where data were collected from medical records of patients admitted with clinical diagnosis of COPD in B. P. Koirala Institute of Health Sciences (BPKIHS), a tertiary level University hospital in eastern Nepal from April 15, 2014 to October 15, 2014. Our inclusion criteria:

1. Age group of more than 40 years.

2. Patients hospitalized with primary diagnosis of AECOPD

Exclusion criteria:

1. Patients with underlying structural heart disease, Cardiomyopathy, Congenital heart disease or left sided heart disease in the present or past

2. Patients with other chronic or terminal condition like cancer, transplant or HIV.

Data items and Definitions:

Diagnosis of COPD was made using GOLD criteria which includes the presence of a postbronchodilator FEV1/FVC $<0.70$ along with appropriate symptoms like dyspnea, chronic cough 
medRxiv preprint doi: https://doi.org/10.1101/2021.07.14.21260238; this version posted July 18, 2021. The copyright holder for this preprint (which was not certified by peer review) is the author/funder, who has granted medRxiv a license to display the preprint in perpetuity.

It is made available under a CC-BY 4.0 International license.

or sputum production, and/or history of significant exposures to noxious stimuli like cigarette smoke or household smoke from biomass fuel. Acute exacerbation of COPD (AECOPD) was diagnosed clinically based on the symptoms of increased chronic cough with or without sputum production, progressive dyspnea and progressive limitation of activity with significant exposure to noxious particles like tobacco smoke, occupational dust or household air pollution (biomass fuel smoke) or in patients with past medical history of AECOPD. Exclusion of other possible explanations and diagnosis for increased cough, dyspnea or limitation of activity example Congestive heart failure, Bronchiectasis, Interstitial Lung Disease was done with the help of Clinical history, ECG, ABG, Spirometry, Echocardiogram, Chest X-ray and Lab parameters.

Statistical analysis and Ethical Clearance:

Ethical clearance was obtained from the Institutional Review Board (IRB) of University Hospital BPKIHS. The data collection was done by two authors independently from the medical record of BPKIHS. We made a proforma and excel sheet to input all the data collected in various headings. Data analysis was performed by using SPSS software (Version 26.0, 2020; SPSS Inc., Chicago, IL). Chi square test was performed to see the association and a 2 -tailed $\mathrm{p}$ value of $<0.05$ indicated statistical significance. We did not perform Univariate and multivariate regression analysis due to limited data collected during the study.

Results:

We included 256 patients with clinical diagnosis of Acute exacerbation of COPD patients in our study. The mean age of our patients is 69 years. We have illustrated the bar graph of prevalence 
medRxiv preprint doi: https://doi.org/10.1101/2021.07.14.21260238; this version posted July 18, 2021. The copyright holder for this preprint (which was not certified by peer review) is the author/funder, who has granted medRxiv a license to display the preprint in perpetuity.

It is made available under a CC-BY 4.0 International license .

of co-morbidities in patients hospitalized with AECOPD during the time frame in figure 1.

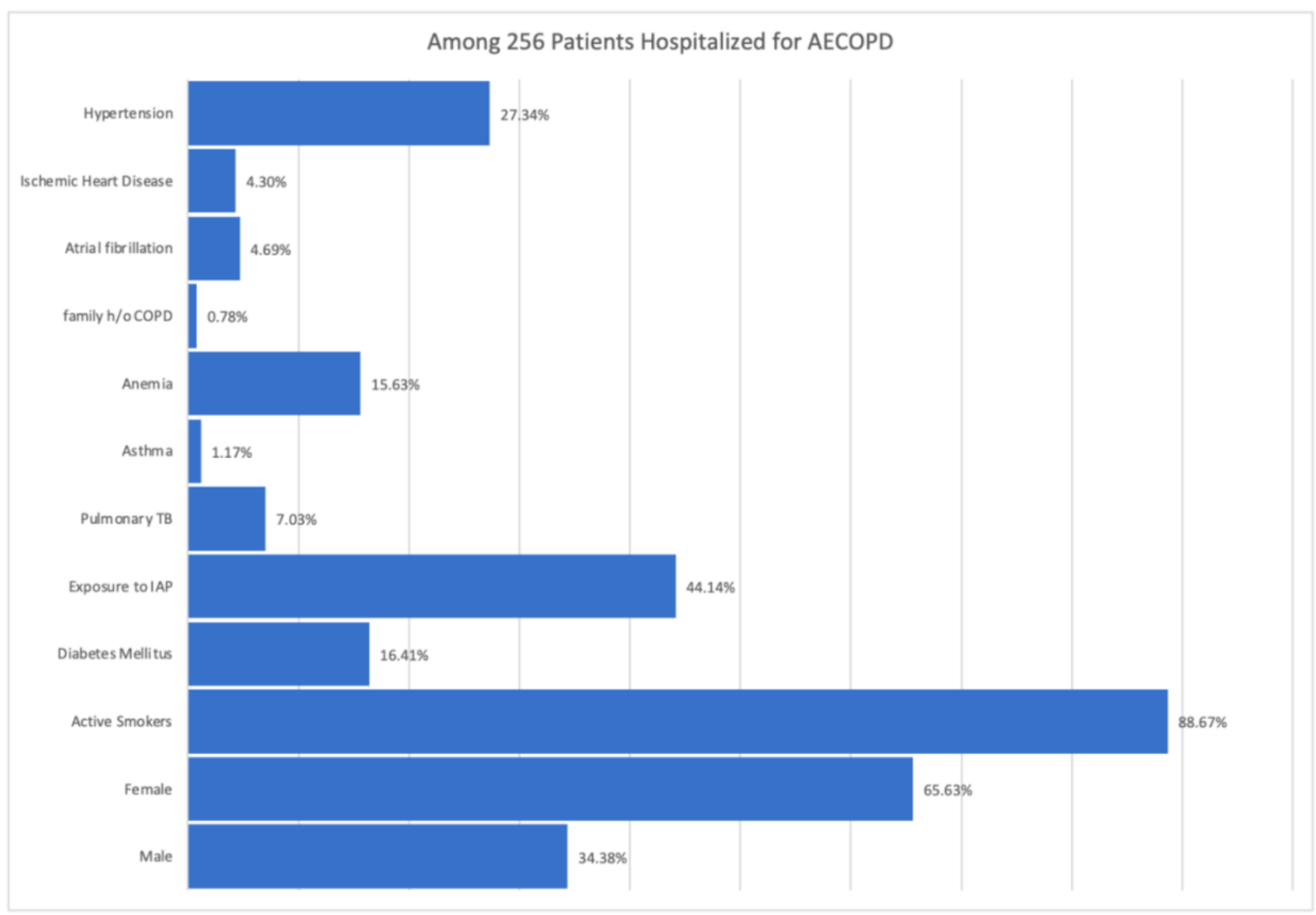

Figure 1: Prevalence of Comorbidities in Patient Hospitalized with AECOPD

IAP= Indoor air pollution TB: Tuberculosis

Of the 256 patients with the primary diagnosis of AECOPD, mean age was 69 years, $65.63 \%$ $(n=168)$ were female, $34.38 \%(n=88)$ were males, $88.67 \%(n=227)$ were active smokers, $16.41 \%$ $(n=42)$ were diabetic, $44.14 \%(n=113)$ were exposed to household air pollution, $7.03 \%(n=18)$ had pulmonary tuberculosis, $1.17 \%(n=3)$ had underlying asthma, 15.63\% $(n=40)$ were anemic, $0.78 \%(\mathrm{n}=2)$ had history of COPD in family, $4.69 \%(\mathrm{n}=12)$ had underlying Atrial fibrillation, $4.30 \%(n=11)$ had ischemic heart disease, and $27.34 \%(n=70)$ were hypertensive. Compared to 
medRxiv preprint doi: https://doi.org/10.1101/2021.07.14.21260238; this version posted July 18, 2021. The copyright holder for this preprint (which was not certified by peer review) is the author/funder, who has granted medRxiv a license to display the preprint in perpetuity.

It is made available under a CC-BY 4.0 International license .

males, $64.32 \%(n=137)$ of active smokers were females $\mathrm{p}=0.299,76.19 \%(\mathrm{n}=32)$ of diabetics were females $p=0.155,72.86 \%(n=51)$ of hypertensive were females, $p=0.143,50 \%(n=6)$ of underlying Atrial fibrillation occurred in females $\mathrm{p}=0.350,57.50 \%(\mathrm{n}=23)$ of underlying anemia occurred in females $\mathrm{p}=0.278,100 \%(\mathrm{n}=3)$ of asthmatics were females $\mathrm{p}=0.553,44.44 \%$ $(n=8)$ of Pulmonary tuberculosis occurred in females $p=0.070)$, and $78.76 \%(n=89)$ of indoor air pollution exposure occurred in females $\mathrm{p}<0.001)$.

Discussion:

Our study shows the higher incidence of hospitalization for AECOPD in females of EasternNepal and this can be explained by high exposure to IAP/biomass fuel smoke as well as high prevalence of smoking in females, compared to male. The combined effect of active and passive smoking along with indoor air pollution may also have contributed to the higher association of female gender with development of COPD. This is plausible from the socio-cultural aspect of Nepal where females mostly work indoors and houses still use biomass for fuel which generates a lot of indoor smoke (2). The study by Jain et al also showed higher association of IAP and COPD with female gender having a prevalence of $89 \%$ (11). A meta-analysis by $\mathrm{Hu} \mathrm{G}$ et al also showed the additive effect of smoking with IAP to cause significant damage to the lungs leading to the development of COPD and its complications (12). This explains the increased incidence of AECOPD in female gender in Eastern-Nepal due to higher IAP exposure and smoking habits in female compared to male. 
medRxiv preprint doi: https://doi.org/10.1101/2021.07.14.21260238; this version posted July 18, 2021. The copyright holder for this preprint (which was not certified by peer review) is the author/funder, who has granted medRxiv a license to display the preprint in perpetuity.

It is made available under a CC-BY 4.0 International license.

There is paucity of data on hospitalized patient with AECOPD and the gender based differences in the prevalence of comorbidities (13). Various studies have reported the prevalence of diabetes in patients with COPD from 1.6-16\%(14). The study by Curkendall et al found the prevalence of DM as $14.5 \%$ and HTN as $40.6 \%$ in patients with COPD (15). The use of chronic steroids in patients with COPD can be associated with the increased risk of having DM in these patients. A study by Mahishale et al found the prevalence of DM and HTN in the 2432 COPD subjects was $25.94 \%$ and $37.25 \%$ respectively which is higher than reported by our study. However, our study differs from other studies as our population includes hospitalized patients with AECOPD. His study reports that severe COPD( GOLD stage 3 or 4) was associated with a higher risk of DM (odds ratio OR 1.6, 95\% CI 1.2-2) and HTN (OR 1.6, 95\% CI 1.4-1.9)(16). This is supported by the study by Mannino et al which reports that after adjusting for age, sex, race, smoking, body mass index and education, subjects with GOLD stage 3 or 4 COPD had a higher prevalence of DM (odds ratio (OR) 1.5, 95\% confidence interval (CI) 1.1-1.9) and hypertension (OR 1.6, 95\% CI 1.3-1.9). Patient with more co-morbidities like diabetes, hypertension, and cardiovascular disease were associated with a higher risk of hospitalization and mortality especially in patients with severe COPD (17).

Our study has several limitations including smaller sample size, lack of proper adjustment of all the potential confounder, and bias in the study design. Moreover, since it was done in easternNepal in a single hospital setting, it may not be generalizable to the overall population. The retrospective chart review is prone to a lot of biases including selection bias, measurement bias, and observer-expectancy bias. Many important information may have been missed during the documentation. However, all efforts are made to decrease the bias, including complete chart 
review and second review of charts. We did not comment on in-hospital mortality or readmissions in our study due to the cross-sectional nature of our study and lack of in-hospital mortality as one of our variables. Our study highlights that we need larger studies to comment on the gender-based differences in patients with AECOPD.

Conclusions:

Our study highlights females of Eastern-Nepal have higher association to indoor air pollution exposure compared to males and this association was found to be statistically significant. The higher incidence of AECOPD hospitalization in females in this population can be explained by these findings. We need larger studies to explain the complex association between female gender and AECOPD.

FUNDING: NONE

Conflict of Interest: We have no any conflict of interest for this study and this study is not funded by any party.

\section{References}

1. Global Initiative for Chronic Obstructive Lung Disease. Global 
medRxiv preprint doi: https://doi.org/10.1101/2021.07.14.21260238; this version posted July 18, 2021. The copyright holder for this preprint (which was not certified by peer review) is the author/funder, who has granted medRxiv a license to display the preprint in perpetuity.

It is made available under a CC-BY 4.0 International license.

strategy for diagnosis, management, and prevention of COPD 2020 report. goldcopdorg/gold 2020 report. 2020 .

2. Bhandari R, Sharma R. Epidemiology of chronic obstructive pulmonary disease: a descriptive study in the mid-western region of Nepal. Int J Chron Obstruct Pulmon Dis. $2012 ; 7: 253-7$

3. Weitzenblum E. CHRONIC COR PULMONALE. Heart. 2003;89(2):225.

4. Adhikari TB, Neupane D, Kallestrup P. Burden of COPD in Nepal. Int J Chron Obstruct Pulmon Dis. 2018;13:583-9.

5. Weitzenblum E, Chaouat A. Cor pulmonale. Chronic Respiratory Disease. 2009;6(3):177-85.

6. Emmanuel Weitzenblum AUACAURK. Pulmonary hypertension in chronic obstructive pulmonary disease. Pulmonary hypertension in chronic obstructive pulmonary disease. 2013;81(4):390-8--8.

7. Lazarus R, Sparrow D, Weiss ST. Baseline ventilatory function predicts the development of higher levels of fasting insulin and fasting insulin resistance index: the Normative Aging Study. Eur Respir J. 1998;12(3):641-5.

8. Engström G, Hedblad B, Nilsson P, Wollmer P, Berglund G, Janzon L. Lung function, insulin resistance and incidence of cardiovascular disease: a longitudinal cohort study. J Intern Med. 2003;253(5):574-81.

9. Festa A, D'Agostino R, Jr., Tracy RP, Haffner SM. Elevated levels of acute-phase proteins and plasminogen activator inhibitor- 1 predict the development of type 2 diabetes: the insulin resistance atherosclerosis study. Diabetes. 2002;51(4):1131-7. 
medRxiv preprint doi: https://doi.org/10.1101/2021.07.14.21260238; this version posted July 18, 2021. The copyright holder for this preprint (which was not certified by peer review) is the author/funder, who has granted medRxiv a license to display the preprint in perpetuity.

It is made available under a CC-BY 4.0 International license.

10. Chung KF. Cytokines in chronic obstructive pulmonary disease. Eur Respir J Suppl. 2001;34:50s-9s.

11. Jain NK, Thakkar MS, Jain N, Rohan KA, Sharma M. Chronic obstructive pulmonary disease: Does gender really matter? Lung India. 2011;28(4):258-62.

12. Hu G, Zhou Y, Tian J, Yao W, Li J, Li B, et al. Risk of COPD from exposure to biomass smoke: a metaanalysis. Chest. 2010;138(1):20-31.

13. Decramer M, Janssens W. Chronic obstructive pulmonary disease and comorbidities. The Lancet Respiratory medicine. 2013;1(1):73-83.

14. Chatila WM, Thomashow BM, Minai OA, Criner GJ, Make BJ. Comorbidities in Chronic Obstructive Pulmonary Disease. Proceedings of the American Thoracic Society. 2008;5(4):549-55.

15. Curkendall SM, deLuise C, Jones JK, Lanes S, Stang MR, Goehring E, et al. Cardiovascular Disease in Patients with Chronic Obstructive Pulmonary Disease, Saskatchewan Canada: Cardiovascular Disease in COPD Patients. Annals of Epidemiology. 2006;16(1):63-70. 16. Mahishale V, Angadi N, Metgudmath V, Eti A, Lolly M, Khan S. Prevalence and impact of diabetes, hypertension, and cardiovascular diseases in chronic obstructive pulmonary diseases: A hospital-based cross-section study. J Transl Int Med. 2015;3(4):155-60.

17. Mannino DM, Thorn D, Swensen A, Holguin F. Prevalence and outcomes of diabetes, hypertension and cardiovascular disease in COPD. European Respiratory Journal. 2008;32(4):962. 